\title{
Roots, Branches, Blossoms, and Briars: Cultural Colonialism of the Mountain Arts in West Virginia Christine Ballengee Morris, PhD
}

\author{
The kingdoms of Experience \\ In the precious wind they rot \\ While paupers change possessions \\ Each one wishing for what the other has got \\ And the princess and the prince \\ Discuss what's real and what is not
}

(excerpt from "Gates of Eden" by Bob Dylan)

Dylan, Bob. (1973). Writings and Drawings. New York: Alfred A. Knopf, Inc.

In this thesis, lexamine the affect cultural colonialist institutions in West Virginia has had on the Mountain Culture, artists, arts and transference process. This is an ethnographic study. Interviews, observations, written material, and videos were used to substantiate the interviews with artist and institutional administrators. The results of the examination showed conflict and contradiction. Issues such as denial to exhibit art, stereotyping and misrepresentation of the culture and art, cultural differences, and decolonialization are explored.

By examining the lives and art of the Mountain Cultural artists of West Virginia at the close of the twentieth century, this study investigates outsiders' control of the cultural arts and ramifications of this control on the arts, artists, and the Mountain Culture. In prior studies, regional culture has been construed in simple terms as the locus of folk ideology or a set of doctrinal structures underwritten by traditional authority. In this study, regional culture encompasses material resources, value systems of community, time, place, and cultural perspectives. Culture reflects a particular history and set of socioeconomic conditions which are mirrored in the arts through style, language, and approach. This approach to the study of regional culture is in sharp contrast to prevailing works that have romanticized West Virginia Mountain Culture or dismissed it as the locus of exploitative policies imposed by agents of cultural capitalism.

This research is an ethnographic study. Written data, material culture, historical data, interviews and observations were collected and analyzed. The interviewees were male and female ranging from $35-75$ years old. Mountain Cultural artists and administrators of organizations that capitalize on West

Marilyn Zurmuehlen's Working Papers In Art Education 1994-1995 
Virginia Mountain Cultural Arts were interviewed. Clifford (1986) states that the danger of ethnography is that because data are based on oral accounts, ethnography is at best "true fictions," inherently biased and incomplete. It is for this reason that triangulated inquiry was utilized as the structure in this study. Triangulated inquiry is a qualitative ethnographic approach in which social phenomena are observed in their natural setting, but supplemented with other data such as diaries, photographs, video, audio tapes, and newspaper accounts to provide a richer understanding of a complex social event (Sevigny 1978). This helps eliminate the "fiction" that Clifford states occurs when the only data utilized comes from interviews. In this study, I have utilized magazine articles and books written in the past twenty years, newspaper articles written in the past three years, films and videos made in the past twenty years, and interviews.

I interviewed administrators and staff of institutions that purport to perpetuate Mountain Cultural arts of West Virginia. The organizations are: Department of Culture and History, Charleston, West Virginia; Augusta Heritage Center, Elkins, West Virginia; and West Virginia Parkways, Economic Development and Tourism Authority, Beckley, West Virginia. The choices of institutional representatives were based on position within the institution, availability, and willingness to be interviewed.

The artists were chosen because of their artistic experience, their extensive relationship with organizations in West Virginia that perpetuate and/or document the cultural arts, and their commitment to their culture. I spoke informally with artists at festivals and meetings about their artistic experience and their involvement with the institutions under examination. The artists I selected to be interviewed are those who have worked for Augusta Heritage Center, Department of Culture and History, and West Virginia Parkways, Economic Development and tourism Authority, have experience in several art forms or have organized arts functions, are members of the Mountain culture, have been active in reformation activities, and were willing to be interviewed.

\section{Statement of the Problem}

There are two groups with opposing views and values vying for economic success in West Virginia. There are outsiders whose origins are outside the West Virginia Mountain Culture, who are in positions which allow them to instruct, judge, change and/or organize Mountain Cultural art forms. The second group are insiders, comprised of those who are born into or reared in the Mountain culture, who instruct, create, and/or create organizations based on their cultural art form. In the current cultural struggle, 
the outsider has gained wide recognition as the perpetuator of Mountain Cultural arts by exploiting institutional policies that are not congruent with the philosophy of the Mountain Cultural artists. The outsider sees the insider as no longer necessary for the transference of cultural arts knowledge.

Outsiders have learned to imitate the style and are now transferring their imitation to each other. An additional component in the paradigm is that this generation of insiders is not perpetuating themselves as quickly and as effectively as are the outsiders. The insiders are excluded from venues controlled by the outsiders' national network power base. Outsiders limit the insiders' access to productions, performances, and interviews. This exclusion is a method of "culturecide".

The exclusion or limited use of insiders is not the specific policy of any organization, but is an accepted practice employed by institutional administrators. Why this practice develops, who gains from this type of discrimination, what roles the outsiders have maintained in the cultural arts, and how the insiders have been affected are questions which will be explored in this study.

What occurs is not a case of taking Mountain cultural arts for display or ownership, removing the context and replacing it with a commodity value as in tourist art (Whisnant, 1983). Instead, there is pilfering of the product, redefining the content and method of pedagogy, imitating the outsider's version of the insider, and claiming the Mountain Culture as their own. It is not about objects, but about people. This is not about influence, but about intrusion. It is not about appreciation, but the redefinition by others to make a safe representation of Mountain Cultural art by eliminating the context of that art. It is not specifically about race, gender, or region. It is about the differences of values, beliefs, and traditions of cultures. It is not about style or technique. It is about the living history of a group of people and how that history relates to today. This is not about the past but the ability to understand the past and use that knowledge in the light of history to cope with and understand the past and use that knowledge in the light of history to cope with and understand conditions today.

In October 1992, West Virginia's Department of Culture and History sponsored a meeting with artists and State Festival Administrators and staff. At this meeting, an attitude of stagnation and oppression was expressed by the Mountain Cultural artists. These artists were frustrated by the lack of state support and with exploitation. The West Virginia Mountain Cultural artists expressed concerns about organizations that utilize non-West Virginian Mountain Cultural artists to represent their culture and arts and about how to reach the younger generation effectively to ensure the continuation of the

Marilyn Zurmuehlen's Working Papers In Art Education 1994-1995 
West Virginia Mountain Cultural arts. These issues, cultural colonialism, transference, stereotyping, self determination, economics and the impact of these issues on the arts will be explored in this study of ownership of the Mountain Cultural arts in West Virginia.

Previous Appalachian studies and theories have addressed the "they" and "us" issue, utilizing a colonistic theory, as I do in this study, by referring to colonialization in a historical context with writers such as David Whisnant, Allen Batteau, and Helen Lewis, suggesting that it does not exist today. Traditional historians concentrate on historical events from an above view that reflects a white male perspective. Folklorists and anthropologists, who utilize a material culture theory, often view people and objects as the same thing. This approach dehumanizes those they seek to understand or explain. The vast majority of these studies are conducted by those who are from outside the culture being examined. The anthropological concept of culture probably would never have been invented, except for the fact that the colonial theater of operations necessitated a knowledge of culture in order to control the people and to legitimize the control. Discovering, documenting, and classifying a culture confirms difference and re-confirms the colonialist's agenda. Other researchers do not take into account the oppressive activities and colonialistic history of outsiders in West Virginia; therefore, their research objectifies the culture and leads to self glorification. What "they" did for "us." As an insider, I cannot utilize the traditional historical, folkloric, or anthropological perspectives. I see culture as living, dynamic, always changing, and spiritual. I am not burdened with the self-serving folkloric notion that the culture died in the 1940 's; I know better. To be understood, we must speak for ourselves. The outsiders project their biases and lack of understanding of the culture; therefore, the view of the culture at which they arrive and present is flawed and skewed.

Within the new historical approach and feminist critical pedagogy are arguments that objective research is impossible. I subscribe to both. Choices made, perspectives taken, and methods of analysis employed are naturally subjective; therefore, biases are always present. My personal experience, research, and interviews with Mountain Cultural artists and administrators of West Virginia arts institutions have led me to conclude that cultural colonalization exists within the Mountain Cultural arts of West Virginia.

\section{Colonialism in West Virginia}

Colonialism and internal colonialism are theoretically based on Marxist ideology that capitalism is the center of inequality. Although economics is a part of the situation, the theory is essentialist and reduces the complex socio- 
psychological, economic phenomenon to a simple explanation. Cultural colonialism expands the colonial model beyond capitalism because capitalism is not the foundation of cultural colonialism. Cultural differences, cultural misinterpretation, cultural exploitation for economic gain serves that purpose. The dominant culture ethnocentrically creates or takes control of institutions whose stated policy is to preserve the culture through educational courses, showcases, festivals, documentation, and tourist shops. The paradox is that individuals from the dominant culture become experts and judges, who then redefine the culture and the arts by institutional policies that determine who and what will be a part of the institution. Anytime cultural arts are commodified, the arts are bound to marketing rules and are no longer controlled by the culture from which they sprang. What the institution winds up preserving is an ethnocentric vision of what it believes the culture should be rather than that which is real. Those of the institutions state they are preserving the culture; however, their attempts at preservation have inexorably altered the cultural arts and changed the natural evolution of the culture. The colonialist attempt to change culture to fit a model set forth by the colonizer and the economic exploitation of the cultural arts and artists lead to a cyclical announcement by the institutions that the culture is dying due to modernization. With each cycle, a group of old artists is discovered and marketed which seems to keep the culture on $\theta$ the edge of extinction and is an excellent marketing tool to increase sales, class attendance, and tourism and to maintain institutional power.

The first stage of cultural colonialism occurs when outsiders establish art education courses to promote economic and social development for insiders. The outsiders establish themselves as experts of the culture and arts; creating non-cultural criteria to judge and exploit the art. In the second stage, insiders try to gain a share of control within the colonial institutions. In stage three, the colonizers view themselves as insiders and replace insiders with outsiders who imitate the cultural art forms. West Virginia Mountain Cultural artists are now in the final stage of cultural colonialism.

During the 1930 's, those from the outside proclaimed themselves as the authority and were not challenged by the insiders. By virtue of their assumed status and accrued power, they established credibility with foundations and publishing companies. One outcome of cultural colonialism is the re-definition of goods and services which satisfies the colonizer's agenda of economic gain. For example, in the case of Berea College's coverlets, the decision to improve quality included changing the traditional patterns, and creating a "new" tradition for the purpose of marketability. When outside criteria are used, boundaries are re-established and a stratification of the cultural arts occurs. These boundaries set up a need for a 
system to determine authenticity and purity, which brings about the stagnation of the arts into stereotypes. By the 1930s, the first stage of cultural colonialism was in place throughout Appalachia.

The cultural colonialism which began in the 1930s was institutionalized in the 1970s. Many political and economic factors came into play in the 1960s and 1970 s which affected the exploitation of West Virginia arts. National media attention on poverty in West Virginia helped to create President Johnson's. War on Poverty. Federally supported VISTA (Volunteers In Service To America) workers were sent into the area with little training or cultural knowledge (Anderson, 1993). Many counterculture youths, desiring to escape the dominant culture, also sought asylum in the mountains. Disenchanted with their own culture, these colonizers sought refuge by adopting cultures that provided relief in places that led them to find their "indigenous self" or the "pioneer within." Outsiders came to overt political power in 1976 with the gubernatorial win by John D. "Jay" Rockefeller IV of New York. The interest of the general public in West Virginia Mountain Cultural arts and socio-political movement converged and brought together groups of people with divergent agendas and cultures.

During this period, The National Endowment of the Arts (NEA), under the direction of Livingston Biddle, stressed grassroots projects and initiated the Folk Arts Program as an independent division. Grants were plentiful and were given to state agencies for distribution to communities and individual artists. The NEA was convinced by outside experts, including Sharon Rockefeller (Governor jay Rockefeller's wife), that the Mountain Cultural arts, as represented in the 1930 s were quickly dying. The NEA worked hard to preserve them by funding any project that attached itself to Appalachia. West Virginia was invaded by outsiders carrying tape recorders and cameras. Their lack of knowledge of the Mountain Culture resulted in misrepresentation of the culture and the treatment of other outsiders as insiders. Festival proceeds, documentation material, and art objects were stolen. David Trend (1992) examined culture, art, education, and politics in the United States and stated that the NEA itself was a coloniaiizer, dominating all the arts by the funding choices it made. He also argued that the NEA was overly concerned with image and used image as criteria for funding. The United States Government was embarrassed by the nationwide publicity accorded West Virginia's poverty. This embarrassment could partially explain the massive federal funding. Good public relations and a positive image were needed to repair the rent in the social fabric brought about by the political turmoil which occurred during Viet Nam War era. Altina Waller (1988) explored cultural differences between outsiders and insiders in West Virginia and stated that outsiders believed that an inferior culture was to blame for the years of

Marilyn Zurmuehlen's Working Papers In Art Education 1994-1995 
poverty and that cultural enlightenment would cure the problem in Appalachia. Cultural enlightenment and the creation of a marketable image helped motivate federal funding for West Virginia. This funding fulfilled the government's external need for self-aggrandizement without regard for the Mountain Cultural need for self determination of identity in the arts, culture, and economic opportunity.

The West Virginians, who were struggling for cultural and political efficacy, allowed the outsiders who represented themselves as experts to join them in their efforts. What the insiders didn't realize was that the outsiders' agenda was not the same as their own. The second stage of cultural colonialism occurs when the insiders decide to claim their culturai identity and efficacy within the system which unbeknownst to them, is taking the culture away. Larry Rader, a Mountain Cultural artist sums it this way:

We let the music and culture slip through our fingers into their hands and then we have to stand around on the outside waiting to be invited back into our own music. But we've done a very poor job, the West Virginia people. We can't bitch too much. We gave it to the other people, let them come in and take it away from us. (Interview, September 1993)

Administrators of newly formed institutions defined the arts in a traditional, anthropological manner. Policies were initiated which ensured the continuation of the frozen-in-time version of the arts. Younger artists who were seeking a place in the market as well as teaching positions were not aware that their arts had been institutionally appropriated until outsiders declared insiders' art as inauthentic because it did not sound or look like the revivalist's forms. The Mountain Cultural artists found they were being judged by colonialists' standards that honored nostalgic versions and they could not meet those standards because the culture had not remained static.

The present day status of the cultural arts in West Virginia is a result of the policies and practices of the 1970s. Today, outsiders have established themselves as the authorities in organizations that promote colonialism. As an example, Augusta Heritage Center in Elkins, West Virginia, utilizes instructors born and raised outside the culture to teach Mountain Cultural arts, although knowledgeable insiders are available and qualified to teach (Blevin, interview, September 1993). This institution utilizes insiders to validate its cultural standing in order to receive grants from the state or the NEA. The outside instructors are hired each year according to how many points they accumulate during their employment: the more the better. They receive a predetermined number of points for good evaluations, high 
workshop attendance, and they receive fifty points if they bring in a "real" West Virginia cultural artist for the aftemoon. This show and tell attitude is an example of how Augusta Heritage views the culture and people which it exploits. By what can only be described as a lack of ethics, Augusta ignores the traditional, oral, and cultural method of transference and promotes a material culture attitude toward the ritualistic format. Changing the process of transference, the use of outsiders, and stereotyping the arts to meet Augusta Heritage Center's representatives' financial goals has resulted in a redefinition of the Mountain culture. The institution has established itself as the cultural arts expert, and through a hegemonic process, nationally perpetuates its version of the cultural arts as inclusive.

The final stage of cultural colonialism occurs when the outsiders view themselves as insiders and the insiders' culture is reduced to a style and/or a historical memory. The institution's representatives interdict the artists who do not agree with them by branding them as inauthentic. This keeps the artists from posing a threat. The Mountain Cultural artists who choose to ignore the colonial situation and cooperate with the institutions are supporting institutionalized colonial policy. In Ward Churchhill's examination of the colonialization of the Native American, and as a Native American activist for self determination, he concludes, "in advanced colonial settings, the colonized are convinced to administer and impose on themselves the policies and regulations set forth by their colonizers"(1993, p 380). The participation of the colonized insider in governing and outside power over the insider brings up the question, how is colonialism maintained? According to interviews I have conducted with Mountain Cultural artists and administrators of art institutions, I have identified the two following means of maintaining cultural colonialism in West Virginia: institutional authority and cultural stereotyping.

Those in authority decide who and what will be included in the overall view of how the culture is seen and presented. Their judgments re-detine the arts and the culture. Those who are judging the arts and crafts are not insiders, which may explain why many insiders are excluded. The older traditional craftspeople will probably not pay much attention to the Parkways; the danger lies in what will happen to the younger ones now, and in the next generation, as they try to accommodate themselves to the Parkways ideal. When Blevin(1993) was asked why outsiders are used to teach West Virginia Mountain Cultural arts, she stated that people of the culture were not needed to teach the arts, just good teachers. Whisnant (1983) concluded from his research of the historical intrusion in Appalachia that this attitude is a failure to understand the culture. The outsiders' flawed understandings of the social 
structure, intellectual habits, manners, and economic arrangements are not congruent with the actual culture.

It is necessary to understand the consequences of cultural colonialism to determine needs and methods for decolonialization. The institutional representatives emphasize heritage which places its representation of the culture in the past. Having experts from outside the culture teach the arts communicates that the culture no longer exists. The culture and arts have been diluted to a style. The Mountain Cultural artists define their culture and arts as traditionally based but expressed in their time and place. The Mountain Cultural artists want absolute autonomy over their culture and arts. Many cultures are in the process of post-colonialization which espouses an inclusion of multiplicity. If West Virginia is to overcome a patemalistic state, the artists must pursue strategies and courses of action that will lead to decolonialization. This will not mean the preservation of a romantic status quo. The Mountain Cultural artists must control the direction of change and the identity of their beneficiaries. For a cultural revolution to begin, the oppressed must first know they are oppressed and then employ methods to counter the oppression (Trend 1992). What methods are needed and who will take part in the revolution? Those entrenched in the hegemonic establishment are sure to contest. Change means loss, and loss will be resisted

To liberate oneself from oppression is to unite in solidarity, break the silence, take responsibility, make a commitment to work for change and to value diversity within the culture. Resistance to the hegemony is in its formative stages. There is a growing realization among the Mountain Cultural artists of what has occurred and is occurring. They realize that it is up to them to resist further advances. The form this resistance will take is less clear to them than the realization that change is necessary. The insiders are no longer as firmly in the thrall of the outsiders as they once were. They are aware of their lack of participation in the economic benefits to be derived from the performance and sale of their art. The outsiders have taken the spirit of West Virginia Mountain Cultural arts and with their eschatological approach have stagnated and pickled the arts instead of preserving them. Their replacement is a pre-packaged, pre-fabricated culture with easy to read directions: you, too, can be a West Virginia Mountain Cultural artist.

\section{References}

Anderson, Colleen. 16 November 1993. Interview with Christine Morris. Berkley Springs, West Virginia. Transcript on file with Christine Morris 
Blevin, Margo. 5 September 1993. Interview with Christine Morris. Weston, West Virginia. Transcript on file with Christine Morris.

Churchill, Ward. 1993. Fantasies of the Master Race. Maine:Common Courage Press.

Clifford, James. 1986. Introduction: Partial Truths. in Writing Culture: the Poetics and Politics of Ethnography. Cliford, James \& Marcus, George (eds.) Los Angeles, Califomia: University of California Press.

Rader, Larry. 4 September 1993. Interview with Christine Morris. Weston, West VirginiaTranscript on file with Christine Morris.

Seviny, Maurice. 1978. Triangulated Inquiry: An Alternative Methodology for the Study of Classroom Life. Visual Arts Education 8 (Spring): 69.

Waller, Altina L. 1988. Feu d. North Carolina: University of North Carolina Press. 